\title{
Harvesting orange-headed thrush Zoothera citrina chicks in Bali, Indonesia: magnitude, practices and sustainability
}

\author{
I g N KR I S T I A N T O and PA U L JEP S ON
}

\begin{abstract}
Market demand for the orange-headed thrush Zoothera citrina, a prestigious songbird competition species in Indonesia, is supplied by chicks harvested from Bali Island. Using ethnographic and interview surveys conducted during the 2008-2009 breeding season we established the structure and scale of this trade and investigated means to improve its sustainability in two districts of Bali. We found that well-organized agent networks supplied an estimated 116,000 chicks worth EUR 3.175 million from Bali during the 6-month harvest season. Chicks are harvested when 4-16 days old and exported from Bali when 16-18 days old. Of 50 nests followed $60 \%$ were harvested and just $6 \%$ fledged young. Farmers deploy techniques to improve thrush food supply but lack practices to ensure continued recruitment to the thrush population. The practice of thrush harvesting started in the mid 1990s and is not yet regulated by the traditional institutions (Subak) that govern collective farming practices. Three networks determine the sustainability of the practice: (1) the fraternity of Indonesian songbird keepers, (2) agricultural agent networks, and (3) traditional village institutions. We identify the potential for coordinated forms of self-regulation and thrush population management by Subak and key groups involved in songbird contests. Furthermore, we argue that this would more likely enhance sustainability than interventions by government conservation agencies.
\end{abstract}

Keywords Bali, bird harvesting, community-based resource management, customary institutions, governance, Indonesia, wildlife trade, Zoothera citrina

\section{Introduction}

7 he orange-headed thrush Zoothera citrina is a widespread Asian species occurring in wetter regions of the Indian subcontinent, South-west China and South-east Asia (Clement et al., 2000). The exceptional song characteristics of this and eight other native bird species have interacted with local traditions of birdsong competitions to

IGN KRISTIANTO Kutilang Indonesia Foundation, Sarihardjo, Ngaglik, Sleman, DI. Yogyakarta. Indonesia

PAUL JEPSON (Corresponding author) School of Geography and the Environment, University of Oxford, South Parks Road, Oxford, OX1 3QY. UK. E-mail paul.jepson@ouce.ox.ac.uk

Received 19 May 2010. Revision requested 23 August 2010.

Accepted 8 October 2010. popularize a new form of competition (called Kicau-mania) in the urban culture of West Indonesia (Jepson, 2008). $Z$. citrina is the most popular and prestigious of the species involved and increasing demand since the mid 1990s led to all forest blocks on Java being systematically 'caught out' by 2003 or 2004 (Jepson \& Ladle, 2009).

Recent research on policy approaches to mitigate the negative conservation impacts of Indonesian bird-keeping (Jepson \& Ladle, 2006, 2009, Jepson et al., 2011) revealed that markets for $Z$. citrina are supplied by chicks harvested from agro-forests on the island of Bali. Moreover, reports suggested that this practice was governed by customary village law and might be sustainable. Here we present the results of a study that aimed to: (1) investigate the bodies and practices involved in the harvesting, distribution and selling of chicks, (2) provide an indicative estimate of the number and value of birds harvested, (3) evaluate the potential of traditional village and bird-keeper institutions to govern the sustainability of the practice, and (4) generate recommendations for managing this harvest.

\section{Study area and species}

The tropical island of Bali is divided by a central chain of volcanic mountains that create fertile growing conditions: the island has supported sophisticated societies since $A D$ 900 and is famous for its distinct, vibrant, open and deeply spiritual culture. Cultural landscapes cover all but the higher peaks and agro-forests dominate the landscapes of the central volcanoes. Common tree crops are coffee Coffea sp., cacao Theobroma cacao and clove Syzygium aromaticum intercropped with snakefruit Salacca edulis, coconut Cocos nucifera, banana Musa spp. and various fruit trees including guava Psidium spp., avocado Persea americana, durian Durio zibethinus and mangosteen Garcinia mangostana.

$Z$. citrina is a medium-sized bird with 12 subspecies of which one, Z. c. rubecula, is endemic to Java and Bali (Clement et al., 2000). The species is categorized as Least Concern on the IUCN Red List (IUCN, 2010) and local reports suggest that it was until recently a common breeding bird in the forests, coffee plantations and agro-forests of Java and Bali. The species is a ground feeder that eats a wide range of insects, larvae, worms and fruits. In Bali it breeds during the wetter season from October to May and builds a shallow, cup nest usually in the fork of a small tree. The normal clutch size is $3-4$, the incubation period is $13^{-14}$ days and chicks fledge after 13-14 days (Clement et al., 2000). 
Administratively, the province of Bali is divided into nine districts, 57 subdistricts and 714 villages (Anon, 2009). Most of Bali is farmed by smallholders who either own their land and/or rent part or all of it or are sharecroppers who cultivate another person's land in exchange for a share of the crop. Under this system sharecroppers retain a proportion of the main crop (e.g. coffee, clove and cocoa) and all produce and proceeds from intercropping and livestock and from hunting or collecting activities, including the harvest of thrush chicks.

Customary law is strong on Bali and farmers, whether landholder or sharecropper, are traditionally organized into a Subak. This is a community organization under the traditional village structure usually made up of 40-80 farmer families who collectively develop their economic activities and control the management of plantations in a watershed (Suradisastra et al., 2002). Each Subak may have different customary regulations. Traditional village institutions in Bali command significant authority because they also organize a person's ceremonial life relating to birth, marriage and death.

The study area covered 24 Subak in Pupuan subdistrict of Tabanan District and 21 Subak in Busungbiu subdistrict of Buleleng District, in central Bali (Fig. 1). These localities had earlier been identified as areas where $Z$. citrina harvesting is well established. The combined areas of the two subdistricts is 37,594 ha, which represents $6.7 \%$ of the total land area of Bali. The two subdistricts support $27 \%$ $(13,076 \mathrm{ha})$ of the area of smallholder coffee plantations and $7.6 \%(9,971 \mathrm{ha})$ of native forest on Bali.

\section{Methods}

The study was preceded by a 2-day scoping survey in December 2007 that involved interviews with two local agents at their facilities, four members of the Bali Bird Club who were visiting one agent, and the Bali correspondent of the weekly bird-keeper newspaper Agrobis Burung (circulation 22,000). This study identified the main harvesting regions and the important role of agents in supply chains of thrush chicks.

The main study, involving four researchers, was conducted between October 2008 and April 2009 and involved five elements.

(1) An ethnographic study of a local agent resident in Pupuan subdistrict and his four village agents. The agent was selected because he was among the first traders of $Z$. citrina on Bali and was the only agent willing to allow observation and recording of transactions.

(2) A study of farmers in Busungbiu and Pupuan subdistricts that involved following a farmer family over a 2-week period and assisting with nest searching, monitoring, guarding and chick harvesting activities, and a face-to-face questionnaire survey of 25 farmers conducted during April 2009 in four villages (Tista, Sepangkelod, Bongancine and
Pajahan). This asked questions regarding the year they started harvesting chicks, their harvesting areas, the number of chicks and nests harvested, harvesting practices (11 questions) and their marketing strategy (three questions).

(3) A biological survey of nests in three villages between 5 November and 15 April that involved: locating nest sites through a combination of following land owners on nest searches and independently searching all potential nesting trees in the study plantation every 2 days, identifying the names of nest trees using local knowledge, and recording the fate of each nesting attempt located through repeat visits.

(4) Semi-structured interviews with three traditional leaders (kepala adat and kepala Subak) in each subdistrict to obtain information about customary laws governing harvesting practices.

(5) Semi-structured interviews with three regional agents, four local agents, and four village agents in Tabanan and Buleleng districts to build a wider picture of harvesting practices on Bali and to cross-check the stories and accounts of the local agent (1, above), who was the primary focus of the study.

Data on location of harvesting villages, the year harvesting commenced and chick price was only included in the analysis if it was confirmed by a minimum of three respondents. In addition, information from the ethnographic survey of the local agent (1, above) was cross-checked with the interviews with other agents ( 5 , above). Whenever possible the locations of transactions, nests and other key activities were determined using a global positioning system and plotted on maps and a Landsat 7 ETM+ image (year 2002-2003) using ArcGIS v. 9.2 9 (ESRI, Redlands, USA).

Data on the transactions of the Pupuan local agent were collected by direct observations. In cases where the seller was uncomfortable with the presence of a third party the agent's report of the transaction was used. This detailed data was supplemented by estimates provided by two additional local agents on the number of chicks they sold during the same September 2008 to April 2009 season. These additional local agents were identified by the Pupuan local agent and his regional agent. Tight commercial competition between agent networks and the need to build a close relationship of trust precluded such in-depth research in more than one network. The numbers provided were confirmed by four village agents interviewed. An estimate of the total number of chicks sold from Bali was generated by averaging the two estimated numbers and the observed number and multiplying this by the total number of local agents identified on Bali.

\section{Results}

History and local organization of chick harvesting

The Pupuan local agent and four farmers in Busungbiu subdistrict reported that commercial harvesting of chicks 


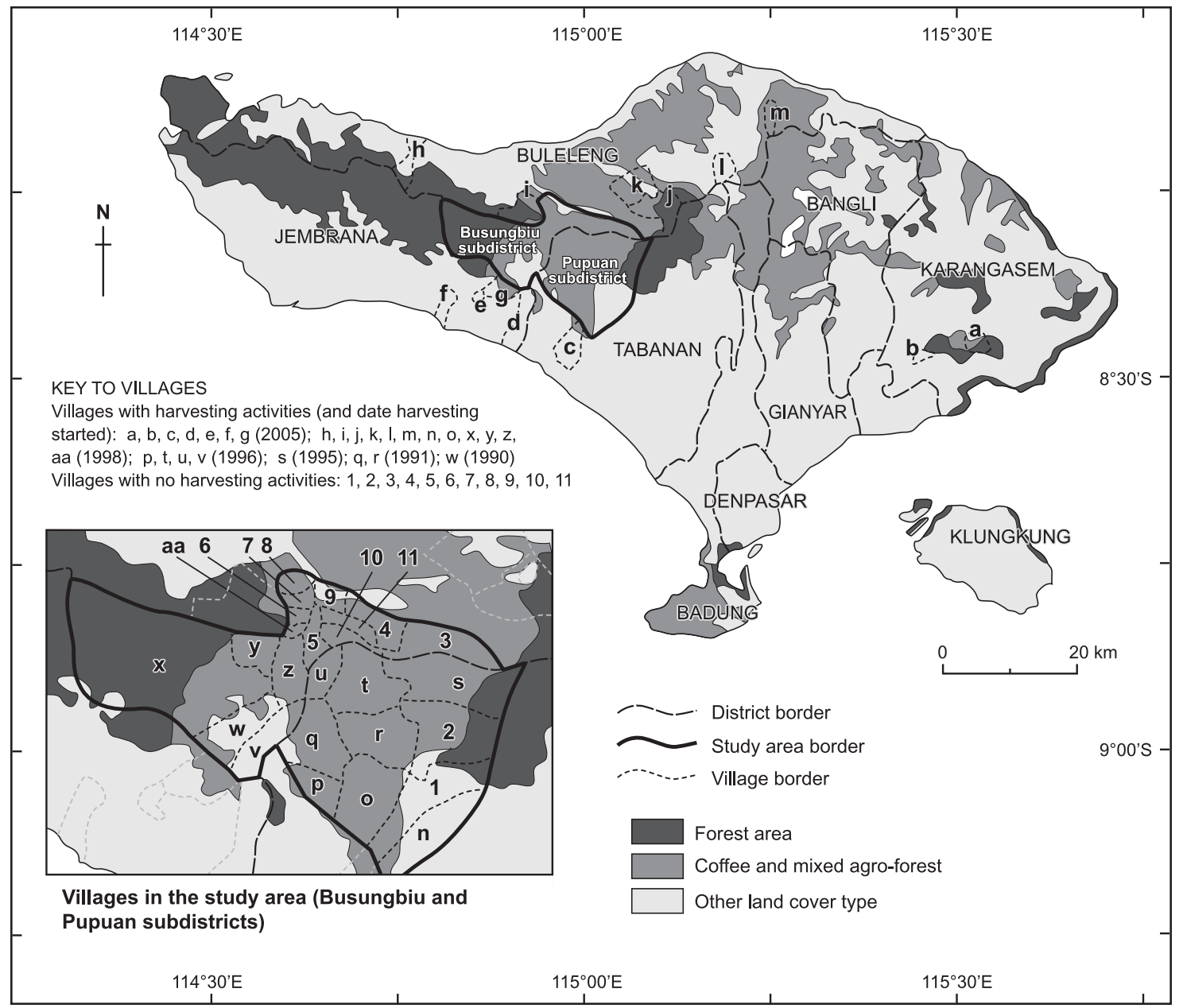

FIG. 1 Location of villages and associated land uses where orange-headed thrush Zoothera citrina chicks are harvested on Bali.

started in the 1990s. Prior to this date some farmers had collected chicks whilst harvesting coffee, to raise for their own enjoyment. The agent received his first significant order in 1995 from a regional agent (a bird trader) based in Surabaya, East Java. The same year he had to move to East Java and therefore he asked his brother to employ some farmers and relatives to collect chicks from areas in Pupuan subdistrict. In Java he made contact with other regional agents and in 1998 two of these, from the cities of Malang and Jember, visited Pupuan to make a direct trading transaction. Subsequently (early 2000) three of his neighbours and relatives entered the business as local agents. In addition, some of his brother's employees transformed themselves into village agents and now sell to other local agents.

A total of 27 villages involved in thrush harvesting were identified. The date of first harvesting was established in 10 of these and ranged between 1991 and 2005, with the majority (seven villages) starting thrush harvesting between 1995 and 1998 (Fig. 1). Respondents reported that Manggissari village (subdistrict Pakutatan, District Jembrana) was the latest village to start thrush harvesting, in 2005. Chicks and, more rarely, eggs are harvested in the rainy season between September and April and numbers peak between November and March (Fig. 2). This coincides with the end of coffee-harvesting activities in August.

\section{Structure and organization of the supply chain}

Semi-structured interviews identified 68 people involved in the supply chain, sourcing chicks from 27 villages involved in thrush harvesting. These people were regional agents

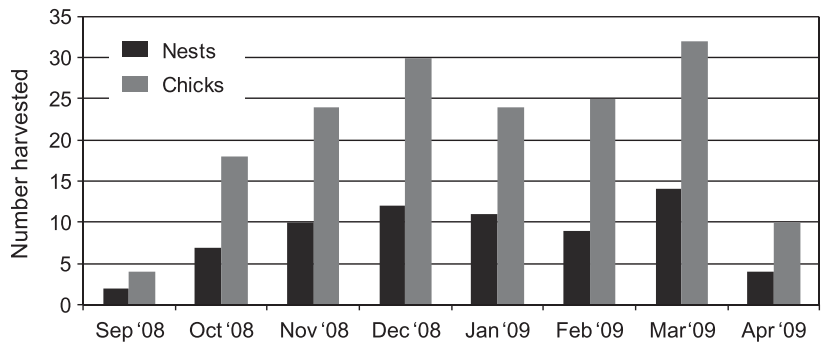

FIG. 2 Number of nests and chicks of $Z$. citrina harvested per month from September 2008 to April 2009 as reported during a face-to-face survey of 17 farmers with total land holdings of 25.4 ha in Tista, Sepangkelod, Bongancine and Pajahan villages. 
(pemborong, eight persons), local agents (pengepul, 12) and village agents (pengecer, 48). Local agents were seasonal bird traders who travel around villages to establish a network of village agents from whom they buy. They seek out farmers in new areas at the beginning of each season in the hope of obtaining birds for a cheaper price. Many are also bird trainers who rear and train selected chicks and sell them as adults. Village agents were coffee farmers who buy chicks from other farmers and other village agents. One village agent interviewed had built an incubator and was buying and successfully hatching eggs. Regional agents are professional bird traders who supply $Z$. citrina chicks directly to bird markets on Java and Bali. They all sell other species besides $Z$. citrina and most have a shop in a bird market. All agents are involved in feeding and rearing chicks. Whilst each agent type will buy young birds (age 3-6 days) they focus on chicks of a different age range (Table 1). This is determined by the distance (time) a chick can be transported without significant risk of death and the timing of a planned transaction with an agent higher up the chain. Local agents and farmers have devised a 9-name classification of chicks (Table 2) to facilitate transaction discussions.

In 2000, village agents developed a means to reliably sex chicks at age 9-10 days. In addition, one agent interviewed together with members of the Bali Bird Club, in December 2007, devised a test of 10 characteristics believed to indicate a chick's potential as a competition bird. These 'prospect' chicks are sold at a premium: six of the 12 local agents interviewed put a ring bearing their name and another with the name of their regional agent on the leg of 'prospect' chicks. Regional agents reported that they later further stratify prices of competition birds according to their juvenile song quality (Ngriwik) and singing (posturing) behaviour (Ngeplong). Female chicks were sold as unsexed birds. The price differential between sexed and unsexed birds was small (c. 10-20\%) because the non-expert buyers cannot differentiate males from females.

The consumer price index adjusted range of thrush chick prices increased significantly from the mid 199os until the 1997 economic crisis. It then showed a small but steady decline until the 2005-2006 season, after which it rose (Fig. 3). The different agent types form networks based on capital sharing, of which two models were identified: independent investment and joint-investment. In the first type an agent uses either their own capital or that raised from people external to the supply chain. These agents were either new agents or agents who had lost the trust of other agents and who lacked permanent suppliers and buyers. Joint-investment agents access capital from their upperlevel agent. One agent interviewed received capital from more than one upper-level agent. Such capital is similar to a down payment on the right to buy an agreed number of chicks for a given period (normally a season). An 'investor' agent may also buy chicks from other agents and employ his local agent to rear chicks until an agreed age for a fee equivalent to the agreed age-related value increases (Table 3). Both parties in such transactions benefit from guaranteed supply. Moreover, knowledge innovations on the techniques of hand-rearing and sexing are only shared within a joint-investment network. However, because networks may reconfigure each season such knowledge flows relatively freely.

Ten local agents with joint-investment networks involving village agents were identified in Bali in the 2008-2009 harvesting season. The local agent studied received capital from two regional agents and headed a joint-investment network of four village agents (one of whom bought from another agent as well as farmers). The local agent also bought chicks from five independent village agents and sold to 19 other regional agents.

\section{Estimates of numbers and values of chicks harvested}

One of each type of agent relationship was studied in detail during the 2008-2009 season: a local-regional agent relationship involved 162 transactions totalling 14,845 chicks; a local-joint investment village agent involved 70 transactions totalling 1,874 chicks, and a local-independent investment village agent involved 39 transactions totalling 462 chicks. Two local agents interviewed from other trade networks stated that they sell c. 10,000 chicks per season to their regional agents. Multiplying the average of these three local agent figures $(11,615)$ by the number of local agents (10) we estimate that the number of chicks sold from Bali in the 2008-2009 season was 160,000. Assuming these figures and an average 16-day old chick price of IDR 280,000 this represents an export value of IDR 39.2 billion / EUR 3.175 million.

\section{Practices of chick harvesting}

Farmers' wives normally locate thrush nests (19 of 25 farmers interviewed) by either following the species' distinctive song

TABLE 1 The age range of Zoothera citrina chicks traded by different agent types, for 75 and 100\% of transactions.

\begin{tabular}{|c|c|c|c|c|c|c|c|c|}
\hline & \multicolumn{2}{|c|}{ Farmer $(\mathrm{n}=25)$} & \multicolumn{2}{|c|}{ Village agent $(n=2)$} & \multicolumn{2}{|c|}{ Local agent $(n=1)$} & \multicolumn{2}{|c|}{ Regional agent $(\mathrm{n}=2)$} \\
\hline & $75 \%$ & $100 \%$ & $75 \%$ & $100 \%$ & $75 \%$ & $100 \%$ & $75 \%$ & $100 \%$ \\
\hline Age chicks acquired (days) & & & $5-10$ & $3-14$ & $11-16$ & $3-15$ & $15-20$ & $6-30$ \\
\hline Age chicks sold (days) & $5-10$ & $3-14$ & $11-16$ & $3-15$ & $15-20$ & $6-30$ & $24-30$ & $>16$ \\
\hline
\end{tabular}


TABLE 2 An age classification of $Z$. citrina chicks derived from a survey of 25 farmers in the villages of Tista, Sepangkelod, Bongancine and Pajahan (Fig. 1).

\begin{tabular}{|c|c|c|}
\hline Names & $\begin{array}{l}\text { Chick age } \\
\text { (days) }\end{array}$ & Characteristic \\
\hline Merah & $<1$ & All skin is red \\
\hline Mesoet & $1-2$ & $\begin{array}{l}\text { Black strip apparent along } \\
\text { defined tracts of body }\end{array}$ \\
\hline Kemusuah & $3-4$ & $\begin{array}{l}\text { Bunch of white tips growing } \\
\text { on the wing }\end{array}$ \\
\hline Kemujaum & $5-6$ & Emerging of pinfeathers \\
\hline Pullkemujaum & $7-8$ & Pinfeathers on wing are elongated \\
\hline Kemukuas & $9-10$ & Feathers breaking out of sheath \\
\hline Kebag & $11-12$ & Juvenile feathers have emerged \\
\hline Sangkep & $13-14$ & $\begin{array}{l}\text { Juvenile feathers cover all } \\
\text { upper parts of body }\end{array}$ \\
\hline Kincung & $15-16$ & $\begin{array}{l}\text { Tail feathers have emerged: } \\
\text { birds have fledged }\end{array}$ \\
\hline
\end{tabular}

or searching for characteristic nest material on trees. Four tree species accounted for $80 \%$ of nest trees located in three villages (Tista, Bongancine and Pajahan; Table 4) and a dry banana sheath (positioned by the bird) formed the foundation in all but two nests. When a dry banana sheath is located on the tree branches it is carefully checked using a motorcycle rear-view mirror attached to a stick. If the nest is incomplete or without eggs it is checked again after 7 days. During this period the farmer prohibits anyone from approaching the nest area. If a nest contains an egg it is monitored from a distance and viewed again after c. 2 weeks. When a chick is found, its age is estimated (Table 2) and several village agents are approached to see who will offer the best price. Of 25 farmers interviewed, eight (36\%) sold to only one village agent (normally a relative), five (20\%) sold to two and 12 (44\%) to more than two village agents. Once a deal is agreed the village agent and farmer go to the nest site at the agreed date of harvesting. The chick will be harvested immediately if the farmer needs cash or if the chick is at the optimal harvesting age (5-10 days). This is the reported age when the mortality of chicks transferring from wild to hand rearing is virtually zero. Farmers harvested all the chicks found: we found no evidence of their leaving a brood to fledge.

Chicks are harvested together with the nest bowl: the nest foundation is left on the tree as a decoy. All farmers interviewed stated that after harvesting, parent birds will build a new nest within $20 \mathrm{~m}$ of the harvested nest and they will rebuild four times during the breeding season. These accounts were confirmed by direct observation of seven pairs breeding in two plantations. The mean number of nesting attempts per pair studied was 3.86 ( 27 attempts). The mean distance between the farthermost nesting attempts of each pair was $21.25 \mathrm{~m}$ (range $0-51 \mathrm{~m}$ ).

The majority of breeding attempts did not produce fledged young. Of 50 nests located in either incubation or chick stage in Tista, Bongancine and Pajahan villages during the period 5 November 2008 to 11 April 2009 the final status was: harvested by plantation owner (27/54\%), harvested but stolen $(3 / 6 \%)$, predated $(16 / 32 \%)$, destroyed by natural event

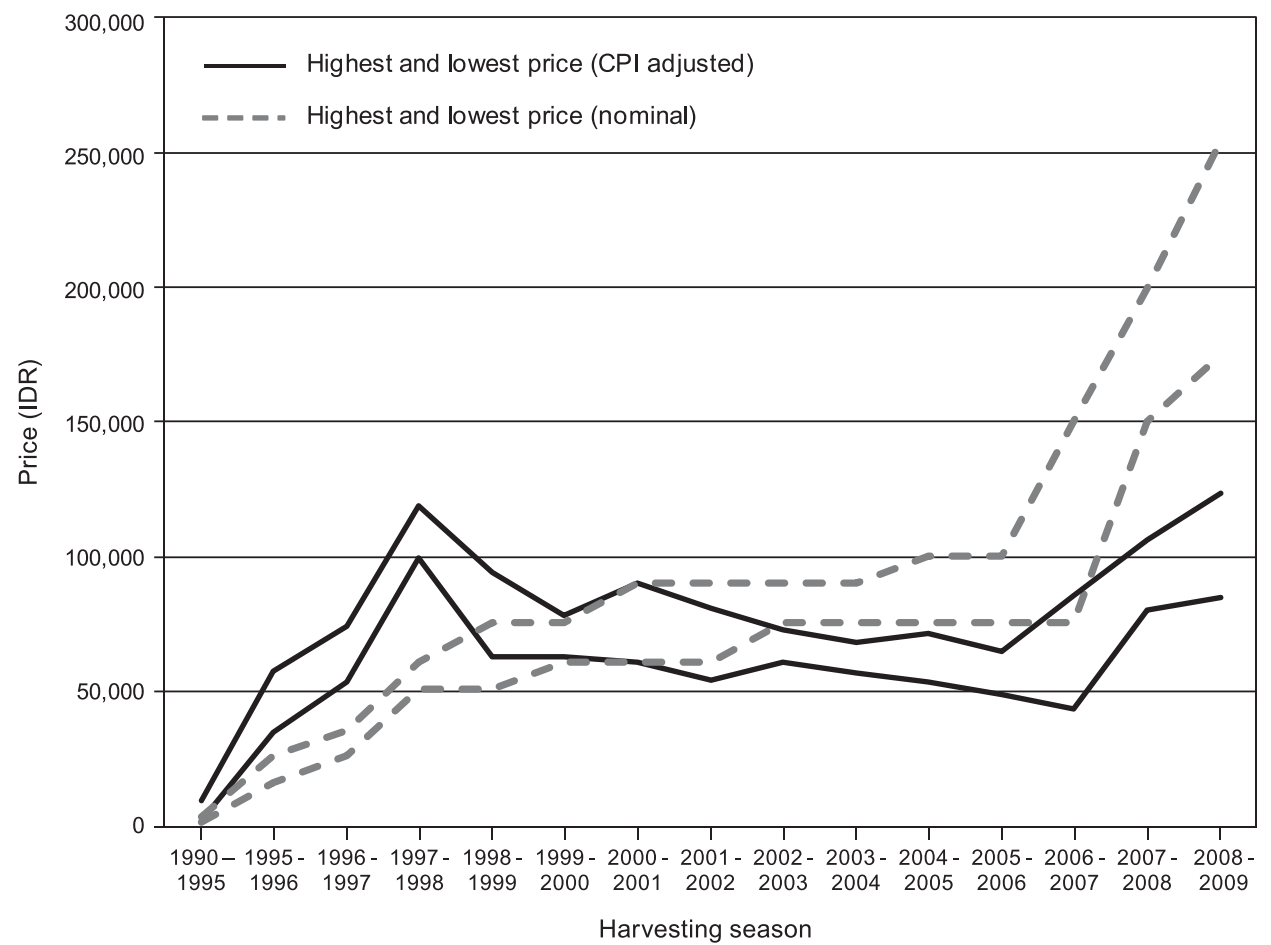

FIG. 3 Changes in nominal and consumer price index (CPI) adjusted highest and lowest prices of Z. citrina chicks in local-regional agent transactions (CPI from World Development Database (2010)) in the harvesting season from 1990 to 2009. 
TABLE 3 Prices of $Z$. citrina chicks at each step in the supply chain in Bali and the typical volumes traded in the 2008-2009 season (prices in 1,000 IDR; 1 EUR = IDR 11,795 in May 2010).

\begin{tabular}{lcccc}
\hline Chick type & Farmer $(\mathrm{n}=25)$ & Village agent $(\mathrm{n}=2)$ & Local agent $(\mathrm{n}=1)$ & Regional agent $(\mathrm{n}=2)$ \\
\hline Premium male price & & & 650 & 1,000 \\
Male price & & 300 & 350 & 550 \\
Female price & 250 & 230 & 290 & Unknown \\
Unsexed price & 270 & Unknown & 400 \\
Volume traded (person per season) & 8 & 1,168 & 11,615 & Unknown \\
\hline
\end{tabular}

$(2 / 4 \%)$, and fledged $(3 / 6 \%)$. Farmers identified squirrel (Tupaia spp.), domestic cat Felis catus, rat (Rattus spp.), an agamid lizard (Brochocela jubata), a colubrid snake (Ahaetulla spp.), Sunda scops owl Otus lempiji, sparrowhawks (Accipiter spp.), and long-tailed shrike Lanius schach as nest predators.

Farmers described three widespread techniques used to improve the productivity of chicks in their plantation: (1) cut grass and hoe the ground around nesting trees to improve foraging areas (17 of 25 respondents), (2) add manure to increase the earthworm population, and (3) prune shade trees, especially Gliricidia sepium, to produce a new sprout that are favoured nest sites. In addition, two farmers said they destroyed the nests of banded pitta Pitta guajana because they view it as a nest-site competitor. They explained that the first two techniques were prompted by observing thrushes foraging on earthworms around livestock excrement.

\section{Governance of chick harvesting}

Interviews with traditional and Subak leaders revealed an absence of customary laws that specifically regulate the harvesting of $Z$. citrina chicks. Theft of chicks is punishable under regulations relating to the theft of property from smallholder plantations and five Subak surveyed operated a similar three-step punishment for theft, involving: (1) a fine of three times the value of the stolen goods, (2) return of the stolen goods to their owner, and (3) an apology in

TABLE 4 The species of nest tree in a sample of 58 nests located in Tista, Bongancine and Pajahan villages, Bali, between 5 November 2008 and 15 April 2009.

\begin{tabular}{llc}
\hline Species & Number & $\%$ \\
\hline Cacao Theobroma cacao & 13 & 22 \\
Lead tree Leucaena leucocephala & 13 & 22 \\
Gliricidia Gliricidia sepium & 13 & 22 \\
Snake fruit Salacca edulis & 8 & 14 \\
Coffee Coffea canephora & 3 & 5 \\
Jackfruit Artocarpus heterophyllus & 2 & 3.5 \\
Clove Syzygium aromaticum & 2 & 3.5 \\
Bamboo Bambussa spp. & 1 & 2 \\
Banana Musa spp. & 1 & 2 \\
Fig tree Ficus spp. & 1 & 2 \\
Candlenut Aleurites moluccana & 1 & 2 \\
\hline
\end{tabular}

front of a meeting of the Subak. If the punishment is ignored Subak will take the case to the court under the Republic of Indonesia's laws. One Subak (Gunung Amerte) had applied a specific punishment for the theft of $Z$. citrina chicks, namely a fine of IDR 10.000 multiplied by the 166 members of Gunung Amerte Subak totalling IDR 1,660,000 (EUR 141)

In Tista, Sepangkelod, Bongancine and Pajahan villages 25 farmers reported that they had agreed rules to restrict the shooting and capturing of mature $Z$. citrina. This initiative has not yet been adopted by a Subak. The shooting and capture of adult $Z$. citrina was recorded in the regions of Unggahan (subdistrict Sririt, District Buleleng) and Pujungan (subdistrict Pupuan, District Tabanan). The farmer in Unggahan said he caught mature birds and released them in a secret place to improve his yield of chicks during the next season. Another farmer in Pujungan said he shot mature birds because he was frustrated by thieves robbing his nests and denying him a good harvest.

\section{Discussion}

This study is the first to document the magnitude and practices of the harvesting of the chicks of $Z$. citrina on Bali and to examine the potential of traditional village and birdkeeper institutions to govern the sustainability of the practice. We did not involve governmental conservation agencies in our analysis because their favoured approaches include protected species legislation and/or catch quotas. The latter are ideally based on models of sustainable offtake derived from demographic data (Robinson \& Redford, 1991). Such approaches would be costly and time consuming to enact in the case of $Z$. citrina on Bali. Moreover, they risk radically changing the dynamics of thrush harvesting and probably in unhelpful ways. For example, the species' status would change from a communal natural resource to state property and insert and legitimize rent-seeking bureaucrats within supply chains. Our study focused on the potential of groups and institutions associated with the chick supply chain to self-govern the harvest.

There is no estimate of the population of Z. citrina on Bali and it is therefore difficult to contextualise the magnitude and impact on the wild population of the estimated annual harvest of 160,000 . Nonetheless, the combination of 
this large number, the intensity and widening area of harvesting, the low ratio of successful to unsuccessful nest attempts $(1: 17)$, and reports of the trapping of adult birds in forest areas suggest that the current model of harvesting is unsustainable. Moreover, because tropical forest birds are relatively long lived and the practice of thrush harvesting is relatively new ( $<15$ years) there is a possibility that harvest levels are being sustained by an ageing parent population that may crash in the future. However, the species quickly relays and will make repeated nesting attempts during a season, supporting the proposition that Z. citrina is pre-adapted to high predation levels and could withstand high offtake if the harvest could be governed appropriately.

We identified three discrete networks that could act to enhance sustainability of the harvest: (1) the fraternity of Indonesian hobbyists engaged with training and competing songbirds and who create particularly high-value markets for birds, (2) agricultural agent institutions that structure the harvesting and trade of thrush chicks, and (3) the traditional Subak institutions. These exhibit a number of characteristics that could be developed and configured into a self-governance model.

The position of $Z$. citrina as the pre-eminent competition songbird seems assured for the foreseeable future thereby creating a stability of future demand and an incentive for these networks to act to assure future supplies. A policy of the influential Pelestari Burung Indonesia (a national organization and respected authority on issues relating to songbird competitions, bird-breeding and conservation) requires that all competitions it accredits must switch to captive-bred birds by 2012. Unfortunately, the popularity and negligible captive supply of $Z$. citrina is creating tensions between Pelestari Burung Indonesia and competition organizers that is undermining support for the policy. One solution is to allow birds from harvesting schemes to be accredited as sustainable. Such an approach appeals to the bird-food companies who are major sponsors of the hobby because it opens new marketing and product opportunities (e.g. speciality chick feed). Moreover, discussions involving Pelestari Burung Indonesia and hobbyist groups concerning the introduction of a bird-certification scheme are well advanced (Jepson et al., 2008).

The desire of the prestigious Bali Bird Club to scout out 'prospect' birds from an early age has established links between the hobbyist fraternity and village agents. We found that some local agents have become active competitors and are keeping some chicks to rear and train for competitions. The networks of agents and the associated systems of finance and reciprocity described reflect and replicate the old and widespread Indonesian institution of agricultural agents. These networks represent a potent conduit of new information on market trends and improved techniques for husbandry and marketing: this could extend to knowledge on managing the thrush-breeding resource.
Whilst our study revealed that thrush harvesting is not yet regulated by the Subak village institutions, this is probably because of the newness of the phenomenon and birds not being a conventional agricultural product. The finding that farmers are employing techniques to increase the species' food source is evidence that the species is transforming from a wild to a managed species. Our engagement with the Subak suggests that given information on the economic potential of the thrush harvesting and the species' breeding ecology they would pass regulations to assure sustainability of supply. The great potential of the Subak is that they allow for collective discussion and agreement and the creating of local norms concerning resource governance.

Based on these analyses we suggest a two pronged approach: (1) Engaging the Subak by attending their meetings and contributing to their discussions over an extended period of time. This would involve co-producing regulations that are both effective and within their authority. Options include a closed season to allow the last brood to fledge and creating small thrush sanctuaries as source habitats. A third option, already being discussed on Bali, is to retain and rear a proportion of chicks harvested for release back into their plantations. (2) Working with the Pelestari Burung Indonesia, song-contest organizers and commercial bird-food sponsors to develop a certification system that establishes and accredits standards for thrush harvesting and engages with hobbyist media and marketing to promote certified birds as possessing higher prestige and quality than their wild-caught counterparts (see also Jepson et al., 2009). This would be challenging but not impossible. It would need to extend existing work on bird certification in Indonesia by incorporating lessons and models from smallholder certification in the forestry and Fair Trade arenas (Taylor, 2005).

In conclusion, this study has shown that the harvest of $Z$. citrina chicks is extensive and embedded within the contemporary Indonesian craze for keeping and competing birds (Jepson, 2008, 2010) and traditional institutions of agricultural production. There is potential to modify present practices to achieve sustainability but this will require a particular type of conservation entrepreneur: one who can build trust and credibility within and across different networks and who can work with a range of different, sometimes competing, perspectives and motivations to facilitate the emergence of a self-governance model.

\section{Acknowledgements}

We thank the Pusat Perpetaan Kehutanan Badan Planologi Kehutanan Departemen Kehutanan Republik Indonesi for supplying the Landsat maps, Wisnu Prabowo, Andri, and Prastowo Hadi for support in data collection, Wahid, Bobi, Ari, Sapte, Zaenal, Samhari, Sumantra, and the Eka family for assistance with fieldwork, the Bali Bird Club team for advice on research areas and introductions to agents. We 
are grateful to Made Prana and Sujatnika for their recommendation to the Rufford Small Grant Foundation, who kindly sponsored the second, substantive survey with grant no 43.07.08, and to the UK Defra Darwin Initiative for funding the first, scoping, survey. We thank two anonymous reviewers for helpful comments.

\section{References}

AnON (2009) Bali in Figures 2009. Http//bali.bps.go.id [accessed 10 April 2010].

Clement, P., Hathaway, R., Byers, C. \& Wilczur, J. (2000) Thrushes. Christopher Helm, London, UK.

JEPSON, P. (2008) Orange-headed thrush Zoothera citrina and the avian X-factor. BirdingASIA, 9, 58-60.

Jepson, P. (2010) Towards an Indonesian bird conservation ethos: reflections from a study of bird-keeping in the cites of Java and Bali. In Ethno-ornithology (eds S. Tidemann \& A. Gosler), pp. 313-330. Earthscan, London, UK.

Jepson, P. \& LAdLe, R.J. (2006) Bird-keeping in Indonesia: conservation impacts and the potential for substitution-based conservation responses. Oryx, 39, 442-448.

Jepson, P. \& LadLe, R.J. (2009) Governing bird-keeping in Java and Bali: evidence from a household survey. Oryx, 43, 364-374.

Jepson, P., Ladle, R.J., \& Sujatnika (2011) Assessing marketbased conservation governance approaches: a socio-economic profile of Indonesian markets for wild birds. Oryx, 45, 482-491.

Jepson, P., Prana, M., Sujatnika \& Amana, F. (2008) Developing a certification system for captive-bred birds in Indonesia. TRAFFIC Bulletin, 22, 9-10.

IUCN (2010) IUCN Red List of Threatened Species v. 2010.3. Http:// www.iucnredlist.org [accessed 15 September 2010].
Robinson, J.G. \& Redford, K.H. (1991) Neotropical Wildlife Use and Conservation. University of Chicago Press, Chicago, USA.

Suradisastra, K., Wahyuning, K.S., Supriatna, Y. \& Hiday at, D. (2002) Institutional Description of the Balinese Subak. Journal Litbang Pertanian, Centre for Agricultural Socioeconomic Research and Development, Bogor, Indonesia.

TAYLOR, L. (2005) A fair trade approach to community forest certification? A framework for discussion. Journal of Rural Studies, 21, 433-447.

World Development Indicators Database (2010) Inflation, consumer prices (annual \%). World Bank, Washington, DC, USA. Http:// data.worldbank.org/indicator/FP.CPI.TOTL.ZG

\section{Bibliographic sketches}

IgN KRISTIANTO is a vice-chairman of the Kutilang Indonesia Foundation. He has been an active participant in the Indonesian bird conservation movement since 1999 and has a particular interest in sustainable use, landscape management and local knowledge. He is actively working to improve the sustainability of the Indonesian pastime of bird-keeping through initiatives to promote captive-bred and sustainably-harvested birds. PAUL Jepson leads an interdisciplinary research group on conservation governance and his current research focuses on four inter-linked themes: how conservation could build influence in situations where the engagement of governmental or corporate bodies is absent, the role and agency of biocultural terms (e.g. extinction, flagships) in producing the institutional practices of conservation, the role of species and technologies in the assembly and behaviour of conservation networks, and the interplay of westernformulated conservation policy instruments with local cultural and resource-management institutions. 